\title{
Analytical Analysis on Impoverishment of Farmers: A Case Study in Gunung Biru, Central Sulawesi of Indonesia
}

\author{
${ }^{1}$ Muhammad Basir-Cyio, ${ }^{1}$ Alam Anshary, ${ }^{1}$ Mahfudz, ${ }^{1}$ Isrun Baso, ${ }^{2}$ Muhammad Nur Ali, \\ ${ }^{3}$ Golar, ${ }^{4} \mathrm{M}$. Rusydi, ${ }^{5}$ Rustam Abdul Rauf, ${ }^{5} \mathrm{Muh}$. Fardhal Pratama, ${ }^{5} \mathrm{Moh}$. Alfit Laihi, \\ ${ }^{6}$ Betty, ${ }^{7}$ Taqyuddin Bakri, ${ }^{8,10}$ Sharifah Zarina Syed Zakaria, ${ }^{9}$ Azlina Abdullah and \\ ${ }^{10}$ Muhammad Rizal Razman \\ ${ }^{1}$ Department of Agroecotechnology, Faculty of Agriculture, \\ ${ }^{2}$ Department of Sociology, Faculty of Social and Political Science, \\ ${ }^{3}$ Department Forestry, Faculty of Forestry, \\ ${ }^{4}$ Department of Geophysics, Faculty of Mathematics and Natural Science, \\ ${ }^{5}$ Department of Agribusiness, Faculty of Agriculture, \\ ${ }^{6}$ Department of Accounting, Faculty of Economy, \\ ${ }^{7}$ Department of Language and Art Education, Faculty of Education and Teacher Training, \\ Tadulako University, Palu 94118, Indonesia \\ ${ }^{8}$ Research Centre for Environmental, Economic and Social Sustainability (KASES) \\ Institute for Environment and Development (LESTARI), \\ ${ }^{9}$ Social, Environmental, Developmental Sustainability Research Centre (SEEDS), \\ Faculty of Social Sciences and Humanities (FSSK), \\ ${ }^{10}$ Research Centre for Sustainability Science and Governance (SGK), \\ Institute for Environment and Development (LESTARI), Universiti Kebangsaan Malaysia (UKM), \\ 43600 Bangi, Selangor, Malaysia
}

\begin{abstract}
This study provides evidence that acts of terror that have hit the people of Central Sulawesi Province of Indonesia for decades due to the outbreak of terrorist groups in Gunung Biru (Blue Mountain) which caused trauma and anxiety that directly affect the economic condition of the community. The analytical analysis study was conducted in three locations, namely, Poso, Sigi and Parigi Moutong District which have direct access to Gunung Biru. The socio-psychological data were collected using phenomenological and ethno-methodological approaches to develop a chronology of socio-anthropological problems, ranging from anxiety, fear, deadlock and trauma to terror that disturbs the work of peace. The level of loss of farmer's incomes over the last 10 years was calculated from farmer's receipts generated from converted agricultural lands before and after the presence of the terrorist groups. The results show that the fertility of the soil chemistry and the physics of the farmland around Gunung Biru are included in the category of moderate to high impact. Socio-psychological symptoms of heavy and severe anxiety levels were very high at $31.0 \%$ and the severe trauma rate was $53.4 \%$, due to the terrorist group operating on Gunung Biru. As a result of such tremendous anxiety and trauma, tens of thousands of farmers have not dared to work on their farms, since, 2005. Loss of farmer's income due to terrorist threats in Gunung Biru amounted to Rp. 90,109,601,406/year which resulted in impoverishment, thus, most of the farming families could not afford to send their children from junior high school to senior high school, especially, to college.
\end{abstract}

Key words: Analytical analysis, socio-psychological income, Gunung Biru, farmer's incomes, tremendous, trauma

\section{INTRODUCTION}

Terrorist actions that have threatened the people of Central Sulawesi Province for decades began to impact the economy in the last 10 years. The East Indonesia Mujahidin (MIT) area serious threat that has caused a great sense of fear. This MIT terrorist group is known to be cruel and sadistic in its massacres. The existence of

Corresponding Author: Muhammad Rizal Razman, Research Centre for Sustainability Science and Governance (SGK), Institute for Environment and Development (LESTARI), Universiti Kebangsaan Malaysia (UKM), 43600 Bangi, Selangor, Malaysia 
terrorists is not only threatening physically but also psychologically, especially, through prolonged fear and trauma (Karnik and Kanekar, 2014; Levav, 2006; Drury and Williams 2012; Phillips and Pohl 2014; Jeon et al., 2017). Terrorist's treatment of society continues to be felt by families and children whose peace and safety are very disturbed (Pine et al., 2005; Birkeland et al., 2017; Webber and Kruglanski, 2018; Schuurman and Horgan, 2016, Ali et al., 2017). Decisive action against extremist groups must be taken systematically and holistically, so that, they do not develop an ideological rationale (Firmansyah, 2011; Soetriadi, 2008; Webber and Kruglanski, 2018; Schuurman and Horgan, 2016, Khairil et al. 2017). Although, the former leader of MIT has been successfully shot dead, the next cadre comes on as a substitute, so, the MIT group is still operating on Gunung Biru. This condition continues to trigger massive trauma and fear inpeople, especially, farmers, thus, they have not dared to cultivate their agricultural land, since, 2005. The land is fertile but not tilled well or maintained, so, it will not give maximum results (Adiyoga, 1999; Awang-Hashim et al., 2015). The decline in land productivity in addition to the degradation of the soil's physicochemical properties (Basir-Cyio et al., 2017) is also due to the psychological disturbance that befell the farmers. The village government also constantly warns its citizens, especially farmers, not to approach Gunung Biru with the simple reason that MIT members still control the entire territory.

In avoiding Polri and TNI attacks, the terrorist group used a scattering technique (Litha, 2016). Sporadic terrorist acts terrify societies (Chrisman and Dougherty, 2014; Breiger et al., 2014). From the confession of terrorists in Poso who were captured by police officers, they adopted a model of guerrilla warfare acquired during exercises in Mindanao in the Southern Philippines and in Afghanistan. The high mobility ofaterrorist hideout can make it difficult for the security apparatus toarrest them (Usmita, 2012; Bappenas, 2012; Rehman et al., 2017). In addition, the Poso terrorist groups grew stronger by joining MIT to form Jamaah Anshorut Tauhid (JAT) in Poso. Their aim was to break up the concentration of the combined apparatus and facilitate the recruitment of cadres. The cadre of terrorists attempted to maintain their existence and the sustainability of their ideological struggles (Mubarak, 2013; Ritaudin, 2017; Drake, 1998; Bozzoli and Muller, 2011; Breiger et al., 2014). Based on data released by the Central Sulawesi Regional Police in the mass media, the number of JAT members from January 2011-2015 reached 100 cadres. Efforts to realize the plan of JAT's formation have made several mountains practice sites, moving from Mount Mauro Tambarana Poso to Mount Tamanjeka Poso and most recently, Gunung Biru Poso.

The MIT group which was affiliated with the $\pi$ network and $\mathrm{Al}$ Qaeda leaders is a very frightening group of people in Central Sulawesi, especially, people living in three districts adjacent to Gunung Biru, namely, Sigi, Parigi Moutong and Poso District where Gunung Biru is located. Of the approximately 23,000 households that have access to Gunung Biru, 6,900 (30\%) obtain food and plantation products from their farms around Gunung Biru. As subsistence farmers, theirplot sizes, ranging from $0.5-1.5 \mathrm{~h}$ are relatively narrow but able to meet the needs of family life (Anonymous, 2016a-c).

The acts of terror greatly affect both social life and the social economy (Jabareen, 2015; Fahs and Swank, 2017), especially in the agricultural sector, both food crops and plantations. Farmers face a dilemma because on the one hand they have to work on their farms to get food and plantation production but on the other hand they are required to keep themselves and their families away from sporadic and sudden terrorist attacks. The terrorists carried out their actions brutally and inhumanely towards the farmers who were working on the land. Some were forcibly taken and or even killed for no apparent reason. This unfavorable condition caused all the agricultural land and plantations controlled by the community to beneglected (Kollias et al. 2011; Gill, 2012).

This study focuses on abandoned and unmaintained farmland conditions as well as estimates of economic losses and disadvantages experienced by farming communities who owned gardens around Gunung Biru in Poso due to socio-psychological and economic disturbances such as: fear, anxiety and economic losses of farming enterprises experienced during the last 10 years. Abandoned land causes a decline in agricultural productivity of food crops and plantation crops continuously, thus, affecting the availability of food and purchasing power implicated in the impoverishment process (Frouz 2017; Ojanen et al., 2017). In poor condition, farmers cannot afford to pay for their children's education whether they want to continue their education to junior high, high school or college. Poverty experienced by farmers is massive in all aspects of socioeconomic life of the community (Mihai et al., 2015; Zhang, 2014; McNamara et al., 2017).

\section{MATERIALS AND METHODS}

Study area: This research is a mixed-method study that uses quantitative research on the general condition of the 


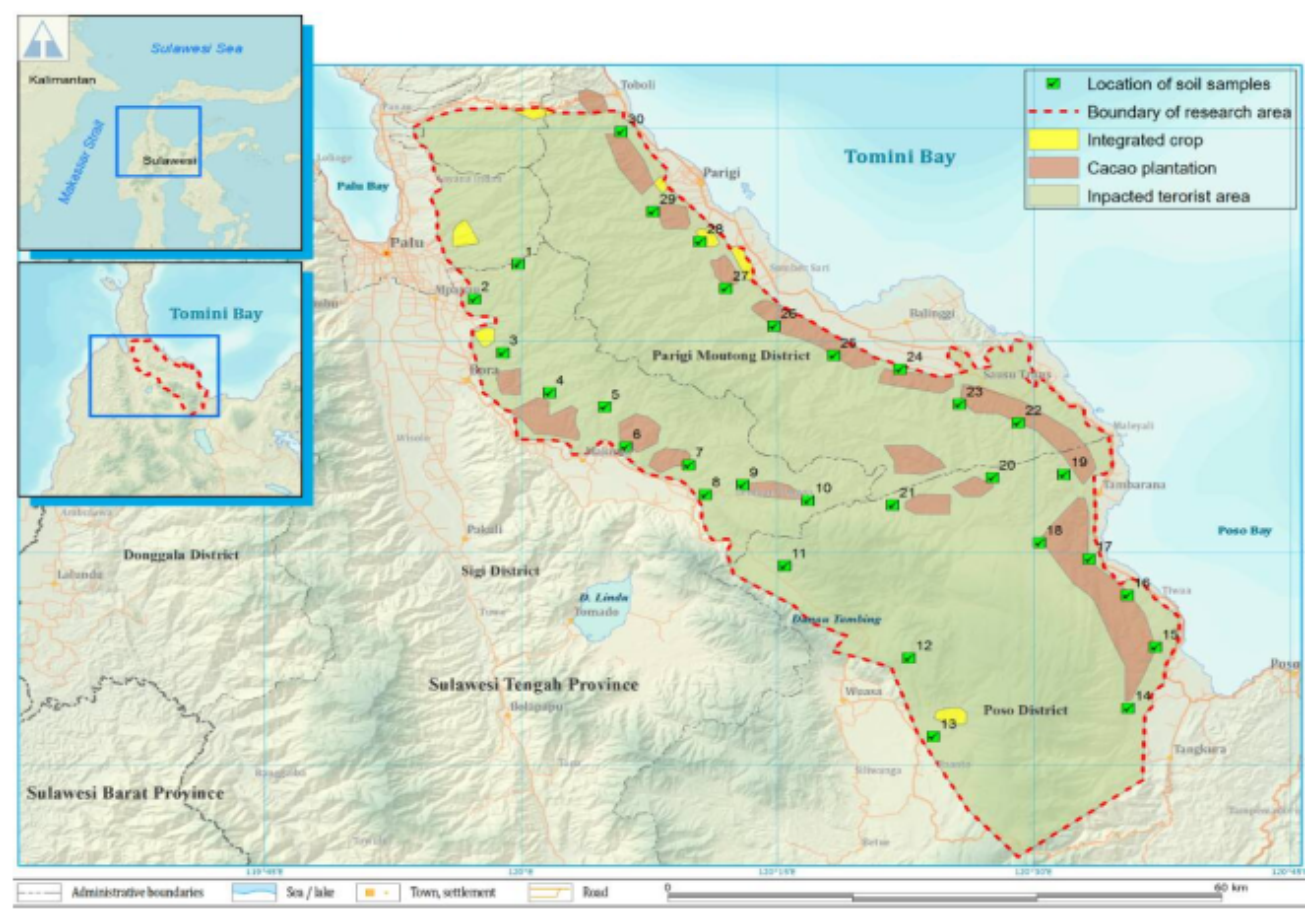

Fig. 1: Map of Gunung Biru and study area; Map of research area and points of soil sample

agricultural land, Post-Traumatic Stress Disorder (PTSD) and farmer income in the locations, i.e., Poso, Sigi and Parigi Moutong District Central Sulawesi Province was conducted in March 2016-January 2017. Agricultural land in the vicinity of Gunung Biru (Fig. 1) has been known for its soil fertility level from some previous studies in terms of its physicochemical properties, productivity potential and types of commodity worth developing (Basir-Cyio et al., 2006; Isrun et al., 2014; Isrun, 2016).

Respondents: There were 27 respondents in the research, consisting of 15 community leaders (five people each district) plus 12 from the government. The number of respondents was determined by purposive sampling: there were 150 people who owned land around Gunung Biru with 30 in Poso District, 70 in Sigi District and 50 in Parigi Moutong District.

Data collection; Socio-psychological symptoms of respondents (Farmers and informants) while working: The socio-psychological data of the study were obtained through interviews and questionnaire instruments. In-depth interviews used a phenomenological approach with the assumption that social facts that appear on the surface were phenomena hidden behind the minds of informants. In addition an ethno-methodological approach was used to explore the ideas and actions of informants in order to find and interpret their frames of mindand respond to their symptoms observed from their attitudes and behaviors (Jailani, 2013; Jeon et al., 2017). Socio-psychological symptoms measured in this study werethe levels of anxiety and trauma experienced by respondents due to the acts of terrorism in Gunung Biru. Anxiety-level instruments were measured using an anxiety questionnaire according to the Hamilton Rating Scale for Anxiety (HRS-A) consisting of 14 groups of anxiety symptoms. Each symptom group was scored between 0 and $4(0=$ no symptoms, $1=$ mild, $2=$ moderate, $3=$ heavy, $4=$ severe $)$. The degree of anxiety was classified into five groups (Hamilton, 1959; Yusuf et al., 2012; Jeon et al., 2017; Awang-Hashim et al., 2015): <14(not anxious), 14-20 (mild), 21-27 (moderate), 28-41 (heavy) and 42-56 (severe). The trauma in this study was Post Traumatic Stress Disorder (PTSD) as measured by a modified Impact of Event Scale-Revised (IES-R). This scale is used as a tool for detecting PTSD based on the existing criteria in DSM-IV. The IES-R measures the severity of the interference with the choice of answers: 0 (never), 1 (rare), 2 (sometimes), 3 (often) and 4 (very often). The categories of total scores on IES-R are shown as follows (Hyer and Brown 2008): <26 (mild), 26-43 (moderate) and $\geq 44$ (severe).

Data analysis; Estimated loss of farmers income: The estimated loss of farmer's income is calculated using 
farmer's income from before and after the presence of terrorists on Gunung Biru. Farmer's income is formulated as follows (Gittinger, 1986):

$$
\pi=\mathrm{TR}-\mathrm{TC}
$$

Where:

$$
\begin{aligned}
\pi & =\text { Income }(\mathrm{Rp} .) \\
\mathrm{TR} & =\text { Total Income }(\mathrm{Rp} .) \\
\mathrm{TC} & =\text { Total Cost }(\mathrm{Rp} .)
\end{aligned}
$$

Data analysis; Comparison analysis: Quantitativedescriptive analysis was used on every research variable obtained from the data collection either by mathematical approach or statistical approach with $\mathrm{t}$ test of significance level $(\alpha) 0.05$. Data on trends between levels of trauma and anxiety andfarmer's incomes were analyzed by simple regression:

$$
\mathrm{Y}=(\mathrm{a}) \pm(\mathrm{bX}), \mathrm{R}
$$

Where:

$\mathrm{Y}=$ Average income of farmers (Rp./year)

$\mathrm{a}=$ Average farmer's income when there is no security disturbance (Rp./year)

$\mathrm{b}=$ The direction coefficient in which there is a change in income each occurrence of the dynamics of escalation of security (socio-psychological)

$\mathrm{X}=$ The dynamics of the escalation of security (socio-psychological)

$\mathrm{R}=$ Correlation coefficient

\section{RESULTS AND DISCUSSION}

Characteristics of respondents: Table 1 shows that the respondents in this research were mostly male $(63.4 \%)$, the largest age group was $36-54$ years with $41.7 \%$ and most respondents had graduated from either elementary school (36.9\%) or junior high school (27.1\%).
Land potential: The chemical fertility of farmland around Gunung Biru is in the medium to high category indicated by a number of parameters: $\mathrm{pH}-\mathrm{H}_{2} \mathrm{O}(4.80-6.55), \mathrm{KTK}$ medium to high [9.95-23.38 $\left.\mathrm{cmol}(+) \mathrm{kg}^{-1}\right]$, C-Organic (1.53-3.38\%), H-dd [0.52-0.98 cmol $\left.(+) \mathrm{kg}^{-1}\right]$, Al-dd [0.92-1.74 $\left.\mathrm{cmol}(+) \mathrm{kg}^{-1}\right]$. The physical properties are sandy loam texture class (sandy loam) and silty clay with bulk density-p (1.32-2.31 $\mathrm{g} / \mathrm{cm}^{3}$ ) (Table 1) (Basir-Cyio et al., 2006; Isrun et al., 2014; Isrun, 2016).

\section{Socio-psychological symptoms of respondents at work:} Data on socio-psychological symptoms are presented in Table 2. The results of this study, based on the answers of respondents netted through questionnaires, show that the public security problem while working has become the dominant factor behind socio-psychological symptoms with heavy and severe anxiety experienced by 14.4 of respondents severe trauma by $48.0 \%$. Likewise with interview data on informants, the outline was put forward that: locals who generally work and live on agricultural produce were unable to work optimally due to fear, anxiety and trauma from shooting or capture events and murders by terrorists in the vicinity, it was unpredictable when uncertain circumstances for locals would end because although, security operations had already crushed terrorists including their leaders, new cadres have emerged as the successors of their cause, the condition was reinforced by interview data stating that terrorism in Gunung Biru was not merely local but indicated to have global networking through the Philippines, Malaysia, Thailand and subsequently, Afghanistan and the middle East Region including ISIS when the researcher asked, "Why was Gunung Biru chosen as the base point of the struggle?" the answer was that the location was strategic

\begin{tabular}{|c|c|c|c|c|c|c|c|c|}
\hline \multirow[b]{3}{*}{ Characteristic } & \multicolumn{6}{|c|}{ Research location (district) } & & \\
\hline & \multicolumn{2}{|c|}{ Parigi Moutong } & \multicolumn{2}{|l|}{ Sigi } & \multicolumn{2}{|l|}{ Poso } & \multicolumn{2}{|c|}{ Total } \\
\hline & $N(50)$ & Percentage & $N(150)$ & Percentage & $N(150)$ & Percentage & $\mathrm{N}$ & Percentage \\
\hline \multicolumn{9}{|l|}{ Sex } \\
\hline Male & 38 & 76.0 & 96 & 64.0 & 88 & 58.7 & 222 & 63.4 \\
\hline female & 12 & 24.0 & 54 & 36.0 & 62 & 41.3 & 128 & 36.6 \\
\hline \multicolumn{9}{|l|}{ Age group } \\
\hline$<35$ years old & 14 & 28.0 & 45 & 30.0 & 50 & 33.3 & 109 & 31.1 \\
\hline $36-54$ years old & 26 & 52.0 & 57 & 38.0 & 63 & 42.0 & 146 & 41.7 \\
\hline$\geq 55$ y ears old & 10 & 20.0 & 48 & 32.0 & 37 & 24.7 & 95 & 27.1 \\
\hline \multicolumn{9}{|l|}{ Education } \\
\hline No school & 8 & 16.0 & 36 & 24.0 & 36 & 24.0 & 80 & 22.9 \\
\hline Elementary graduates & 40 & 80.0 & 60 & 40.0 & 29 & 19.3 & 129 & 36.9 \\
\hline Junior-senior high & 2 & 4.0 & 42 & 28.0 & 51 & 34.0 & 95 & 27.1 \\
\hline Graduates & & & & & & & & \\
\hline $\begin{array}{l}\text { Graduates of diploma } \\
\text { (Higher education) }\end{array}$ & 0 & 0.0 & 12 & 8.0 & 34 & 22.7 & 46 & 13.1 \\
\hline
\end{tabular}
because it can be a node connected with the other three districts (Poso, Sigi and Parigi Moutong), it was also likely that the region possessed mineral deposits such as gold

Table 1: Characteristics of respondents based on research location 
Table 2: Level of respondent's trauma and anxiety

\begin{tabular}{|c|c|c|c|c|c|c|c|c|}
\hline \multirow{3}{*}{$\begin{array}{l}\text { Socio-psychoologicsl } \\
\text { symptoms }\end{array}$} & \multicolumn{6}{|c|}{ Study location (district) } & & \\
\hline & \multicolumn{2}{|c|}{ Parigi moutong } & \multicolumn{2}{|l|}{ Sigi } & \multicolumn{2}{|l|}{ Poso } & \multicolumn{2}{|c|}{ Total } \\
\hline & $\mathrm{N}(50)$ & Percentage & $N(150)$ & Percentage & $\mathrm{N}(150)$ & Percentage & $\mathrm{N}$ & Percentage \\
\hline \multicolumn{9}{|l|}{ Anxiety level } \\
\hline No anxiety & 3 & 6.0 & 7 & 4.7 & 3 & 2.0 & 13 & 3.7 \\
\hline Mild anxiety & 13 & 26.0 & 27 & 18.0 & 36 & 24.0 & 76 & 21.7 \\
\hline Medium anxiety & 14 & 28.0 & 39 & 26.0 & 40 & 26.7 & 93 & 26.6 \\
\hline Heavy anxiety & 14 & 28.0 & 65 & 43.3 & 54 & 36.0 & 133 & 38.0 \\
\hline Severe anxiety & 6 & 12.0 & 12 & 8.0 & 17 & 11.3 & 35 & 10.0 \\
\hline \multicolumn{9}{|l|}{ Trauma } \\
\hline Light & 18 & 36.0 & 69 & 46.0 & 74 & 49.3 & 161 & 46.0 \\
\hline Medium & 19 & 38.0 & 49 & 39.3 & 57 & 38.0 & 135 & 38.6 \\
\hline Severe & 13 & 26.0 & 22 & 14.7 & 19 & 12.7 & 54 & 15.4 \\
\hline
\end{tabular}

Table 3: Relationship of terrorist activity intensity to trauma and farmer's income

\begin{tabular}{lllc}
\hline Years & Intensity of terrorist activities (A) & Farmer's trauma level (B) (\%) & Averageincome earned(C)(Rp.) \\
\hline 2010 & 3 murders & Severe 53.4 & 570,000 \\
2011 & 2 murders & Severe 50.1 & 602,000 \\
2012 & 10 threats & Mild 22.4 & 743,000 \\
2013 & 2 murders & Severe 54.7 & 460,000 \\
2014 & 8 threats & Mild 21.4 & 756,000 \\
2015 & 2 murders & Severe 55.2 & 411,000 \\
\hline
\end{tabular}

Interview result of farmers and community leaders (2016)

Table 4: Respondent's income by production of cocoa, coconut, rice and corn commodity

\begin{tabular}{lccccc}
\hline District/Type of crops & Land area (ha) & Production & Unit price (Rp.) & Respondent's income (Rp.) & Respondent's income (Rp./ha) \\
\hline Poso & & & & & \\
Cocoa (ton) & 1.50 & 2.5000 & 26.500 & $66,250,000$ & $44,166,667$ \\
Coconut (seed) & 0.75 & 175.00 & 5.000 & 875,000 & $1,166,667$ \\
Rice (ton) & 0.83 & 5.0000 & 7.586 & $37,930,000$ & $45,698,795$ \\
Corn (ton) & 0.50 & 0.5000 & 4.000 & $2,000,000$ & $4.000,000$ \\
Sigi & & & & & $53,000,000$ \\
Cocoa (ton) & 1.00 & 2.0000 & 26.500 & $53,000,000$ & 666.667 \\
Coconut (seed) & 0.75 & 100.00 & 5.000 & 500,000 & $32,500,000$ \\
Rice (ton) & 1.00 & 5.0000 & 6500 & $32,500,000$ & $8,000,000$ \\
Corn (ton) & 0.50 & 1.0000 & 4000 & $4,000,000$ & \\
Parigi moutong & & & & & $53,000,000$ \\
Cocoa (ton) & 1.00 & 2.0000 & 26500 & $53,000,000$ & $10,000,000$ \\
Rice (ton) & 0.65 & 1.0000 & 6500 & $6,500,000$ & $4,166,667$ \\
Corn (ton) & 0.48 & 0.5000 & 4000 & $2,000,000$ & \\
\hline
\end{tabular}

which many residents recently found in the province of Central Sulawesi. There are allegations that terrorist groups survive in Gunung Biru because there are sources of life. The results of interviews with respondents related to land owned on Gunung Biru and the production of the main commodities produced are shown in Table 3 and 4 .

Relationship of the level of trauma dynamics with income: The intensity of the activities of terrorists who continued to approach the agricultural areas triggered a sense of high fear and trauma due to frequent occurrences of slander and massacre. The activities data of terrorist groups accompanied by murder andtrauma rates and farmer's income are presented in Table 3.

Since, 2002 (post-Poso riots) until 2016, security instability in Poso city has been very dynamic, a number of sub-districts are still feeling unhealthy socio-harmonic relations among members of different ethnic and religious communities. Before the riots, good and harmonious social relations withthe attitude of mutual help were highly upheld. However, those whose families were sadly killed became vengeful and some even joined the MIT group to take revenge. Terror acts were controlled from Gunung Biru, a place hard to reach by TNI and POLRI. At a time when the terrorist group needed a supply of food, the agricultural products in the vicinity of Gunung Biru became the target for the MIT group. Farmers grew fearful and traumatized because of threats and slaughter if the farmers were not willing to give up their farm products. The relationship between the level of trauma and the income of farmers working on farmland around Gunung Biru is presented in Fig. 2.

In Fig. 2, farmer's incomes significantly decrease as fear and trauma increase due to escalation of security disturbances by terrorist groups. The decrease was statistically significant at the t-test level $(\alpha) 0.05$. From the formula $\mathrm{Y}=(929,537)-(7,913) \mathrm{X}, \mathrm{R}=0.91$, it can be estimated that the higher the level of trauma and anxiety due to security disturbances, the lower the income level. The constant value of revenue (Rp. 929,337) is interpreted 
Table 5: Loss rate (rupiah/years) based on commodities

\begin{tabular}{|c|c|c|c|c|}
\hline Commodity/source & $\begin{array}{l}\text { Respondent's } \\
\text { income (Rp./ha) }\end{array}$ & $\begin{array}{l}\text { Average income of } \\
\text { respondents (Rp.ha) }\end{array}$ & $\begin{array}{l}\text { Estimated impacted } \\
\text { land area (ha) }\end{array}$ & $\begin{array}{l}\text { Total losses } \\
\text { (Rp./year) }\end{array}$ \\
\hline \multicolumn{5}{|l|}{ Cocoa } \\
\hline Cocoa (Poso) & $44,166.667$ & $50,055,556$ & 1225.0 & $61,318,055.556$ \\
\hline Cocoa (Sigi) & $53,000.000$ & & & \\
\hline Cocoa (Parigi Moutong) & $53,000.000$ & & & \\
\hline \multicolumn{5}{|l|}{ Coconut } \\
\hline Coconut (Poso) & $1,166.667$ & 916,667 & 525 & $481,250.000$ \\
\hline Coconut (Sigi) & 666.667 & & & \\
\hline \multicolumn{5}{|l|}{ Rice } \\
\hline Rice (Poso) & $45,698.795$ & $29,399,598$ & 868 & $25,518,851.406$ \\
\hline Rice (Sigi) & $32,500.000$ & & & \\
\hline Rice (ParigiMoutong) & $10,000.000$ & & & \\
\hline \multicolumn{5}{|l|}{ Corn } \\
\hline Com (Poso) & $4,000.000$ & $5,388,889$ & 518 & $2,791,444.444$ \\
\hline Corn (Sigi) & $8,000.000$ & & & \\
\hline Corn (Parigi Moutong) & $4,166.667$ & & & \\
\hline
\end{tabular}

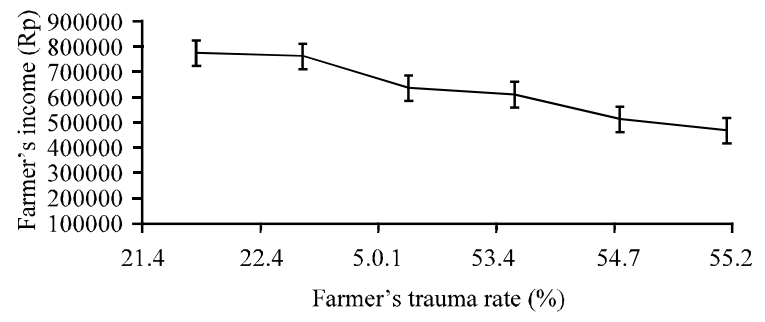

Fig. 2: Relationship between farmer's trauma level and income

as a safe situation without any disturbance while the coefficient of direction (-7.913) indicates that every increase of one unit of disturbance that resulted in trauma will decrease farmer's income by Rp. 7,913.

Farmer's income: Table 4 shows that cocoa production in three research sites averaged 2.17 tons/ha and was the largest contributor to farmer's incomes. The highest rice production in was Poso and Sigi Kabupeten with an average of 5 tons/ha, representing a large market share. Stagnant production of superior commodities that have been supplying local and regional markets is a result of the existence of terrorist groups in Gunung Biru and the fear and trauma experienced by almost all farmers. The intensity of the terrorist group's activities has triggered trauma, leading to the decision that as long as there are terrorist groups, farmland will not be worked. This is also in line with the harsh warnings from local authorities not to approach farmland in the buffer zone of Gunung Biru due to terrorists. Farmer's declining revenue and income are major factors in the process of impoverishment. Mathematically, the revenue of cocoa farming without technological input is the size of production obtained from each crop multiplied by the selling price. The results of interviews with respondents in Sigi District mentioned that the average cocoa production is $1,612 \mathrm{~kg} / \mathrm{ha} /$ year and the acceptance rate is Rp. $45,942,000 /$ ha/year with the selling price of Rp. $28,500 / \mathrm{kg}$. Furthermore, the production cost is Rp. 9,205,550, thus, farmer's income is Rp. $36,736,450$.

Table 5 shows that cocoa commodities provide the highest revenue source (Rp. 50,055,556/ha) and Sigi and Parigi Moutung districts have the same cocoa productivity of 2 tons/ha. The next commodities that may potentially be the source of farmer's income are rice (Rp. 29,399,598/ha) and maize (Rp. 5,388,889/ha). The commodity that needs to be developed is coconut whose production is categorized as low per hectare amounting to Rp. 916,667. The presence of a terrorist group on Gunung Biru has caused agricultural and plantation activities in Gunung Biru to be paralyzed and untreated, resulting in a loss of Rp. 90,109,601,406/year.

The results of this study indicate that agricultural land and plantations in the area of Gunung Biru are fertile, especially for agricultural crops and commodity plantations with moderate to high soil fertility conditions seen from the physicalsoil characteristics of the soil concentration of $\mathrm{pH} \mathrm{H}_{2} \mathrm{O}$ (4.80-6.55), $\mathrm{pH} \mathrm{KCl} \mathrm{(4.90-5.32),}$ bulk density (1.32-2.31 g/ $\left.\mathrm{cm}^{3}\right)$, C-Organic (1.53-3.38\%\%) and N-total (0.14-0.19\%) (Basir-Cyio et al., 2006; Isrun et al., 2014; Isrun, 2016). Other research results indicate that mountainous areas have clay to dust texture with high organic material content that has the ability to hold and absorb water (Ahmad, 2010; Zaiets and Poch, 2016; Brambach et al., 2017). In addition, the physical condition of the soil hasbulk density of $0.9-1.1 \mathrm{~g} / \mathrm{cm}^{3}$ and high porosity, preventing the process of oxygen depletion (Tanveera et al., 2016; Chaudhari et al., 2013; Wasak and Drewnik, 2015). Soils with high fertility rates significantly increase yields (Wasak and Drewnik, 2015; Vanlauwe et al., 2010). Nitrogen (N), Phosphorus (P) and Potassium (K) nutrient content are low but the remnants of existing plants can be utilized by farmers as organic fertilizers. 
Organic fertilizers in addition to being more easily obtained around planting land are also free. Organic fertilizers have advantages over inorganic fertilizers because in addition to releasing macronutrients they also improve the texture and structure of the soil (Panjaitan and Tiurma, 2013; Zulkarnain et al., 2013). In general, the condition of the land is in accordance with the growing requirements required by both food crops and commodity plantations which includes the chemical properties and physical properties of the soil including the depth of solum (Haridjaja et al., 2010).

Before the terrorist group controlled Gunung Biru, the surrounding farming area was a supplier of some of the food needs of the people of Central Sulawesi, especially, of rice and maize. Loss of production from areas around Gunung Biru has affected the availability of food and plantation products, especially, cocoa. The declining production of farm enterprises stimulates the impoverishment process (Esposti, 2014; Felipe et al., 2016; Ozturk, 2017). The imbalance between supply anddemand contributes to the rising of prices (Borychowski, 2015), thus, the selling price of food commodities is difficult to reach due to the decrease of people's purchasing power (Bayramoglu, 2014; Gao and Suss, 2015; Saleuddin and D'Maris, 2018). The existence of the terrorist group in Gunung Biru and Poso has become a serious threat to the people of Central Sulawesi, especially, farmers who have direct access to Gunung Biru. Fear, anxiety and trauma have been the causes of the loss of people's creation and work ability (Robinson et al., 2013).

The results of this study indicate that none of the respondent did not feel disturbed and the dominant feeling is of trauma, followed by anxiety and fear. The higher the security threat, the more fear, anxiety and trauma (Brauch et al., 2011). Most respondents (68.6\%) had socio-psychological symptoms of heavy or severe anxiety with a severe trauma rate of $45.3 \%$. The most dominant anxiety and traumatic feelings eliminate one's morale (Searing et al., 2013; Park et al., 2014; Chung et al., 2018). Anxiety and trauma can also disrupt the socioeconomic life of the community (Brook and Louis, 2008). Even the productivity and creativity of the community tend to decline (Lee, 1996). The decline of farmer's productivity is due to fear and trauma related to work on agricultural land which has been cultivated as their economic resource. In 2013, the heaviest fear level with $68.6 \%$ of respondents reporting fear, resulted in a decrease in productivity indicated by farmer's low income of Rp. 460,000, equivalent to USD 35.38/year, the highest revenue was obtained in 2014 which was Rp. 756,000, equivalent to USD 58.20 /year, during which year the trauma rate was its lowest (43.3\%) and a number ofterrorists were captured. Ongoing disturbances and threats in addition to psychological impacts, also, deprive themof confidence and creativity (Park et al., 2014; Amusan and Ejoke, 2017; Chung et al., 2018). Loss of creativity influences income, decreasing purchasing power (Gao and Suss, 2015; Pirrong, 2017; Joets et al., 2017). The tendency of terrorists to defend themselves on Gunung Biru is a long-term threat to society. It will take the power of the state to protect the community, so that, their productivity can be restored (Wadley et al., 2014; Taffler et al., 2017; Kaluarachchi, 2018).

This study found a new fact: that terrorism in Gunung Biru is not just local but is indicated to have a global network through the Philippines, Malaysia, Thailand and then Afghanistan and the Middle East Region including ISIS. Internationally affiliated terrorist groups have a strong funding source as well as guerrilla tactics (Young and Gray, 2011). Gunung Biru is used by the terrorists as a hiding place due to its strategic location as a node connectingthe other three districts of Poso, Sigi and Parigi Moutong. It is assumed that the region has mineral deposits such as gold which was recently found by a lot of residents in the province of Central Sulawesi. The potential of sufficient natural resources could be the reason for the terrorists to remain inan area as a source of their livelihoods (Maleckova and Stanisic, 2011; Morrison, 2016; Eiselt, 2018). Remote places in the forests and on the mountain are perfect for hiding or as bases of the terrorist's movement, so that, terrorist activities are protected from public observation as well as providing food sources that can sustain their lives (Munthe, 2007).

The data presented describe the socio-psychological atmosphere of the population in the region of Gunung Biru which is indefinite uncertainty, not just about how they can work well to earn sufficient income for their families but also because at times they can become victims of murder by terrorist cruelty. The terrorist group's goal in its operation is to defend its ideological struggle and kill those who threaten its existence (Chertoff, 2008; Ali, 2016). On the macro scale, the neglect of agricultural land has affected the decrease of supply of agricultural products coming from Gunung Biru Region in the form of cocoa, coconut, rice and corn, thus, they lack food and income. Food and income shortages can lead to poverty (Asnawi, 2015). Poverty that is not immediately handled by the government will have an impact on social stability (Stoever and Kim, 2007), if this social situation is not immediately addressed, then it willthreaten the stability of the state (Knight, 2013; Aviles and Grigalunas, 2018). Terrorist threats have caused psychological 
distress, anxiety and panic in society (Waxman, 2011 ; Goodwin et al., 2005). The indirect economic impact of the existence of terrorists is the fear of the farming community to perform their activities (Melnick and Eldor, 2010; Drakos, 2010; Younas, 2015; Kaluarachchi, 2018), so, farmers do not cultivate their land in the Gunung Biru area. This condition causes a huge loss of farmer's incomes. The significant decrease in farmer's incomes in each case increased the fear and trauma caused by the escalation of security disturbances by terrorist groups by Rp. 7,913. This number will continue to grow if there is no guarantee of security from the government. Decrease in income is negatively correlated with the level of trauma experienced by farmers and their families. The correlation between trauma and income conditions is quite close to the correlation coefficient (r) 0.91 with the coefficient of determinant $\left(\mathrm{R}^{2}\right)$ at $83.3 \%$ or a decline in income of $83.3 \%$ due to the trauma experienced by farmers.

Community income from cocoa commodities before the threat of terrorist groups in Gunung Biru amounted to Rp. 50,055,556/ha/year. If the cocoa cultivation area of farmers around Gunung Biru is $1,225.0$ ha, then the loss of income from the cocoa commodity is Rp. 61,318,055,556/year. Likewise income for coconut plants was Rp. 916,667/ha/year or Rp. 481,250,000 with an area of 525 ha. For rice plants, a price of Rp. 29,399,598/ha/year with a total area of 868 ha yields a loss of Rp. 25,518,851,406/year. Following the commodity of corn with the value of Rp. 5,388,889/ha/year and land area of $518 \mathrm{ha}$, the total loss is Rp. 2,791,144,44/year. If the total income lost is added up, it is Rp. 90,109,601,406. Using the exchange rate of USD 1.00 equals Rp. 12,500, the total loss of income of farmers trying to farm around Gunung Biru reaches USD 7,208,768/year. Loss of public income affects the level of community welfare (Arka et al., 2015; Bergh and Bjornskov, 2014). Recovery in conflict areas is urgently needed, especially in Poso Region. The longer the conflict and traumatic sense in a region, the lower the confidence of the regional and international community inthe government's ability to protect its people (Nur, 2015). The presence of terrorists in Poso has contributed to a decline indomestic and foreign tourism. Tourism is one source of Foreign exchange in almost all countries in the world (Hampton and Jeyacheya, 2015; Tomohara, 2016, 2017). Singh (2013) reported that the cessation of activities of terrorist groups had an impact on investment including the decision taken by farmers to re-create their cultivated farming businesses. This shows that the presence of terrorists in a region resulted in the limitation of the regional community's conducting activities both in agriculture and in investing, thus, farmers lose income (Bayramoglu, 2014; Gao and Suss, 2015; Wadley et al., 2014).

Another impact that arises from the prohibition of farmers from cultivating plantation areas on Gunung Biru is that the community has penetrated the conservation area of Lore Lindu National Park. The district government and the security apparatus of the TNI and Polri can provide a safe radius for farmers to be able to work on the plantation area, thus, the surrounding community plantations could provide sufficient additional income for farmers. The anxiety and trauma they have experienced means that farmers, especially, mothers, need to get counseling, not only from religious figures and community leaders but also from special counselors who can provide a sense of security and overcome the anxiety and trauma faced so far. Unresolved anxiety and trauma can disrupt their psyches and thus require a greater cost to overcome (Wiltgen et al., 2015; Gindt et al., 2017; Young-McCaughan et al., 2017).

\section{CONCLUSION}

Anxiety and trauma experienced by farmers and their entire families have caused the loss of creativity of farmers in working on farmland around Gunung Biru. The fertile land is dormant and useless, making the productivity of the land low. Loss of income for farmers has triggered a massive process of impoverishment that has an impact on their low purchasing power to meet daily needs including the inability to send their children to junior high, high school and college.

\section{ACKNOWLEDGEMENTS}

Acknowledgments are conveyed to the Head of the Laboratory of Natural Resources and Environment (Laboratory LASDAL), Faculty of Agriculture, University of Tadulako for service of soil fertility inspection. Then, credits to Community Leaders, Village Heads, Sub-district Heads, Heads of Agriculture and District Security Officers (Parigi Moutong, Sigi and Poso) who provided much important information in this study. Part of the study was conducted by using funding from the research project of (XX-2018-008).

\section{REFERENCES}

Adiyoga, W., 1999. [Several alternative approaches to measuring efficiency or In-efficiency in farming (In Indonesian)]. Agric. Inf., 8: 487-497. 
Ahmad, Y., 2010. [Land fertility assessment in the forest of Mount Sebatung in Kotabaru District, South Kalimantan (In Indonesian)]. J. Hutan Tropis Borneo, 11: $32-37$.

Ali, M.N., 2016. [Study of terrorism in central Sulawesi (In Indonesian)]. Al Ulum, 16: 496-516.

Ali, M.N., M.R. Razman, Z. Ramli and K. Arifin, 2017. Understanding aggressive behaviour to avoid damages through the precautionary principle towards the Sustainable Development Goals (SDGs). J. Food Agric. Environ., 15: 52-55.

Amusan, L. and U.P. Ejoke, 2017. The psychological trauma inflicted by Boko Haram insurgency in the North Eastern Nigeria. Aggression Violent Behav., 36 : 52-59.

Anonymous, 2016a. [Palolo district statistics]. Badan Pusat Statistik Sigi, Central Sulawesi, Indonesian. (In Indonesia)

Anonymous, 2016b. [Statistics of Sausu District]. BPS Parigi Moutong, Central Sulawesi, Indonesian. (In Indonesian)

Anonymous, 2016c. [Statistics of lore utara district]. BPS Poso, Sulawesi, Indonesia. (In Indonesian)

Arka, S., A. Yasa and I.K. Oka, 2015. [The influence of economic growth and income disparity of intercity to the welfare of the people of Bali Province (In Indonesian)]. J. Ekonomi Kuantitatif Terapan, 8: 1-9.

Asnawi, R., 2015. [Climate Change and Food Sovereignty in Indonesia (In Indonesian)]. Tinjauan Produksi Kemiskinan. Sosio Inf., 3: 293-309.

Aviles, A.M. and N. Grigalunas, 2018. Project awareness: Fostering social justice youth development to counter youth experiences of housing instability, trauma and injustice. Children Youth Serv. Rev., 84: 229-238.

Awang-Hashim, R., A. Kaur and M. Noman, 2015. The interplay of socio-psychological factors on school engagement among early adolescents. J. Adolescence, 45: 214-224.

Bappenas, 2012. [Terrorist Prevention and Counting]. Publisher Bappenas, Palu, Sulawesi, Indonesian, (In Indonesian).

Basir-Cyio, M., D. Saiful, B. Isrun, P. Salapu and L. Syamsuddin, 2006. Preparation of map of commodity territories in poso district through land suitability test. Master Thesis, Tadulako University, Palu, Indonesia.

Basir-Cyio, M., Mahfudz, T. Inoue, A. Anshary and T. Kawakami et al., 2017. Impact of the traditional gold mine management on public health and agricultural land: A Study of traditional gold mining in Poboya, Sausu and Dongi-Dongi Village, Central Sulawesi, Indonesia. J. Food Agric. Environ., 15: 115-122.
Bayramoglu, A.T., 2014. The impact of agricultural commodity price increases on agricultural employment in Turkey. Procedia Soc. Behav. Sci., 143: 1058-1063.

Bergh, A. and C. Bjornskov, 2014. Trust, welfare states and income equality: Sorting out the causality. Eur. J. Political Econ., 35: 183-199.

Birkeland, M.S., M.B. Nielsen, M.B. Hansen, S. Knardahl and T. Heir, 2017. The impact of a workplace terrorist attack on employees perceptions of leadership: A longitudinal study from pre-to postdisaster. Leadersh. Q., 28: 659-671.

Borychowski, M. and A. Czyzewski, 2015. Determinants of prices increase of agricultural commodities in a global context. Manage., 19: 152-167.

Bozzoli, C. and C. Muller, 2011. Perceptions and attitudes following a terrorist shock: Evidence from the UK. Eur. J. Political Econ., 27: S89-S106.

Brambach, F., C. Leuschner, A. Tjoa and H. Culmsee, 2017. Diversity, endemism and composition of tropical mountain forest communities in Sulawesi, Indonesia in relation to elevation and soil properties. Perspect. Plant Ecol. Evol. Syst., 27: 68-79.

Brauch, H.G., U.O. Spring, C. Mesjasz, J. Grin and P. Kameri-Mbote et al., 2011. Coping with Global Environmental Change, Disasters and Security: Threats, Challenges, Vulnerabilities and Risks. Vol. 5, Springer Science \& Business Media, Berlin, Germany, ISBN:978-3-642-17776-7, Pages: 1818.

Breiger, R.L., E. Schoon, D. Melamed, V. Asal and R.K. Rethemeyer, 2014. Comparative configurational analysis as a two-mode network problem: A study of terrorist group engagement in the drug trade. Soc. Networks, 36: 23-39.

Brook, C.A. and A.S. Louis, 2008. Social anxiety disorder: A review of environmental risk factors. Neuropsychiatr. Dis. Treat., 4: 123-143.

Chaudhari, P.R., D.V. Ahire, V.D. Ahire, M. Chkravarty and S. Maity, 2013. Soil bulk density as related to soil texture, organic matter content and available total nutrients of Coimbatore soil. Intl. J. Sci. Res. Publ., 3: $1-8$.

Chertoff, M., 2008. The ideology of terrorism: Radicalism revisited. Brown J. World Aff., 15: 11-20.

Chrisman, A.K. and J.G. Dougherty, 2014. Mass trauma: Disasters, terrorism and war. Child Adolesc. Psychiatric Clinics, 23: 257-279.

Chung, M.C., N. AlQarni, M. AlMazrouei, S. Al Muhairi and M. Shakra et al., 2018. The impact of trauma exposure characteristics on post-traumatic stress disorder and psychiatric co-morbidity among Syrian refugees. Psychiatry Res., 259: 310-315. 
Drake, C.J., 1998. The role of ideology in terrorists' target selection. Terrorism Political Violence, 10: 53-85.

Drakos, K., 2010. Terrorism activity, investor sentiment and stock returns. Rev. Financial Econ., 19: 128-135.

Drury, J. and R. Williams, 2012. Children and young people who are refugees, internally displaced persons or survivors or perpetrators of war, mass violence and terrorism. Current Opinion in Psychiatry, 25: 277-284.

Eiselt, H.A., 2018. Destabilization of terrorist networks. Chaos Solitons Fractals, 108: 111-118.

Esposti, R., 2014. On why and how agriculture declines: Evidence from the Italian Post-WWII experience. Struct. Change Econ. Dyn., 31: 73-88.

Fahs, B. and E. Swank, 2017. Exploring stigma of extreme weight gain: The terror of fat possible selves in women's responses to hypothetically gaining one hundred pounds. Womens Stud. Intl. Forum, 61: 1-8.

Felipe, J., C. Bayudan-Dacuycuy and M. Lanzafame, 2016. The declining share of agricultural employment in China: How fast?. Struct. Change Econ. Dyn., 37: 127-137.

Firmansyah, H., 2011. [Management efforts of criminal acts of terrorism in Indonesia (In Indonesian)]. J. Criminal Laws, 23: 376-393.

Frouz, J., 2017. Effects of soil macro-and mesofauna on litter decomposition and soil organic matter stabilization. Geoderma, 332: 161-172.

Gao, L. and S. Suss, 2015. Market sentiment in commodity futures returns. J. Empirical Finance, 33: 84-103.

Gill, P., 2012. Terrorist violence and the contextual, facilitative and causal qualities of group-based behaviors. Aggression Violent Behav., 17: 565-574.

Gindt, M., O. Nachon, L. Chanquoy, S. Faure and R. Garcia, 2017. Attentional bias in Post-traumatic stress symptoms or anxiety. Eur. J. Trauma Dissociation, 1: 159-164.

Gittinger, J.P., 1986. [Economic analysis of agricultural projects]. Master Thesis, Universitas Indonesia, Jakarta, Indonesia. (In Indonesia)

Goodwin, R., M. Willson and G. Stanley Jr, 2005. Terror threat perception and its consequences in contemporary Britain. Br. J. Psychol., 96: 389-406.

Hamilton, M., 1959. Hamilton anxiety rating scale (HAM-A). J. Med., 61: 81-82.

Hampton, M.P. and J. Jeyacheya, 2015. Power, ownership and tourism in small islands: Evidence from Indonesia. World Dev., 70: 481-495.

Haridjaja, O., H. Yayat and L.S. Maryamah, 2010. [Germination of peanut and soybean seeds (Effect of soil bulk density on soil physical properties and seed germinations of peanut and Soybean)]. Ilmu Pertanian Indonesia, 15: 147-152.
Hyer, K. and L.M. Brown, 2008. The impact of event scalerevised: A quick measure of a patient's response to trauma. AJN. Am. J. Nurs., 108: 60-68.

Isrun, B., 2016. Study of specific fertilization recommendation locations in Sigi District. Master Thesis, Center for Assessment of Natural Resources and Environment, Tadulako University, Palu, Indonesia.

Isrun, B., A. Made, L. Syamsuddin and A.R. Rustam, 2014. Study and strategy of dry land management in Sigi Regency. Master Thesis, Center for Assessment of Natural Resources and Environment, Tadulako University, Palu, Indonesia.

Jabareen, Y., 2015. The emerging Islamic State: Terror, territoriality and the agenda of social transformation. Geoforum, 58: 51-55.

Jailani, M.S., 2013. [Variety of qualitative research Ethnography, phenomenology, grounded theory and case studies (In Indonesian)]. Educ. Bio. J. Pendidikan Biol., 4: 41-49.

Jeon, G.S., S.Y. Park and K.S. Bernstein, 2017. Sociodemographic and psychological correlates of posttraumatic growth among Korean Americans with a history of traumatic life experiences. Arch. Psychiatric Nurs., 31: 256-262.

Joets, M., V. Mignon and T. Razafindrabe, 2017. Does the volatility of commodity prices reflect macroeconomic uncertainty?. Energy Econ., 68: 313-326.

Kaluarachchi, N. Y., 2018. Building community resilience in the Re-settlement of displaced communities. Procedia Eng., 212: 443-450.

Karnik, S. and A. Kanekar, 2014. The effects of terrorism on adult mental health: A public health preparedness approach. Global J. Med. Public Health, 3: 1-7.

Khairil, M., M.R. Razman, Z. Ramli and K. Arifin, 2017. Understanding terrorism based on radicalism idea in order to avoid instability for achieving environmental peace and justice the Sustainable Development Goals (SDGs). J. Food Agric. Environ., 15: 48-51.

Knight, J., 2013. The economic causes and consequences of social instability in China. China Econ. Rev., 25: $17-26$.

Kollias, C., E. Manou, S. Papadamou and A. Stagiannis, 2011. Stock markets and terrorist attacks: Comparative evidence from a large and a small capitalization market. Eur. J. Political Econ., 27: S64-S77.

Lee, D., 1996. The hidden cost of workplace trauma. Employee Assistance Professionals Association, Arlington County, Virginia, USA. http://humannatureatwork.com/article/the-hiddencost-of-workplace-trauma. 
Levav, I., 2006. Terrorism and its effects on mental health. World Psychiatry, 5: 35-36.

Maleckova, J. and D. Stanisic, 2011. Public opinion and terrorist acts. Eur. J. Political Econ., 27: S107-S121.

McNamara, P., A. Harvey and L. Andrewartha, 2017. Passports out of poverty: Raising access to higher education for care leavers in Australia. Children Youth Serv. Rev., 59: 182-195.

Melnick, R. and R. Eldor, 2010. Small investment and large returns: Terrorism, media and the economy. Eur. Econ. Rev., 54: 963-973.

Mihai, M., E. Titan and D. Manea, 2015. Education and poverty. Procedia Econ. Finance, 32: 855-860.

Morrison, J.F., 2016. Trust in me: Allegiance choices in a post-split terrorist movement. Aggression Violent Behav., 28: 47-56.

Mubarak, Z., 2013. [The phenomenon of terrorism in Indonesia: Study of aspects of theology, ideology and movement (In Indonesian)]. J. Salam, 15: 240-254.

Munthe, A.G., 2007. [Terrorism: Criminal symptoms of the latest media (In Indonesian)]. J. Hukum Pro Justitia, 25: 1-8.

Nur, E.H., 2015. [Handling of case of terrorism in Indonesia Year 2002-2006 (In Indonesian)]. E. J. Ilmu Hubungan Intl., 3: 17-26.

Ojanen, P., P. Makiranta, T. Penttila and K. Minkkinen, 2017. Do logging residue piles trigger extra decomposition of soil organic matter?. For. Ecol. Manage., 405: 367-380.

Ozturk, I., 2017. The dynamic relationship between agricultural sustainability and Food-energy-water poverty in a panel of selected Sub-Saharan African Countries. Energy Policy, 107: 289-299.

Panjaitan, G.S. and W.S. Tiurma, 2013. [The effect of using organic fertilizer on the nature of soil physics in pare subdistrict (In Indonesian)]. J. Agroknow, 1: 7-12.

Park, S., J.P. Hong, J.N. Bae, S.J. Cho and D.W. Lee et al., 2014. Impact of childhood exposure to psychological trauma on the risk of psychiatric disorders and somatic discomfort: Single vs. multiple types of psychological trauma. Psychiatry Res., 219: 443-449.

Phillips, P.J. and G. Pohl, 2014. Prospect theory and terrorist choice. J. Appl. Econ., 17: 139-160.

Pine, D.S., J. Costello and A. Masten, 2005. Trauma, proximity and developmental psychopathology: The effects of war and terrorism on children. Neuropsychopharmacol., 30: 1781-1792.

Pirrong, C., 2017. The economics of commodity market manipulation: A survey. J. Commod. Markets, 5: 1-17.

Rehman, F.U., M. Nasir and M. Shahbaz, 2017. What have we learned? Assessing the effectiveness of counterterrorism strategies in Pakistan. Econ. Modell., 64: $487-495$.
Ritaudin, M.S., 2017. [The ideology of martyrs death justifies the terror of political violence (In Indonesian)]. J. TAPIs, 8: 1-29.

Robinson, O.J., K. Vytal, B.R. Cornwell and C. Grillon, 2013. The impact of anxiety upon cognition: Perspectives from human threat of shock studies. Front. Hum. Neurosci., 7: 1-21.

Saleuddin, R. and C. D'Maris, 2018. Can inflation expectations be measured using commodity futures prices?. Struct. Change Econ. Dyn., 45: 37-48.

Schuurman, B. and J.G. Horgan, 2016. Rationales for terrorist violence in homegrown jihadist groups: A case study from the Netherlands. Aggression Violent Behav., 27: 55-63.

Searing, E.A., F. Rios-Avila and J.D. Lecy, 2013. The impact of psychological trauma on wages in postconflict Bosnia and Herzegovina. Soc. Sci. Med., 96: 165-173.

Singh, P., 2013. Impact of terrorism on investment decisions of farmers: Evidence from the Punjab insurgency. J. Conflict Resolution, 57: 143-168.

Soetriadi, E., 2008. [Policies on countering criminal acts of terrorism with criminal law]. Master Thesis, Diponegoro University, Semarang, Indonesia. (In Indonesian)

Stoever, K. and A. Kim, 2007. Global health as a factor in economic and social stability. Health Progr., 88: 57-59.

Taffler, R.J., C. Spence and A. Eshraghi, 2017. Emotional economic man: Calculation and anxiety in fund management. Accounting Organizations Soc., 61: 5367.

Tanveera, A., T.A. Kanth, P.A. Tali and M. Naikoo, 2016. Relation of soil bulk density with texture, total organic matter content and porosity in the soils of Kandi Area of Kashmir valley, India. Intl. Res. J. Earth Sci., 4: 1-6.

Tomohara, A., 2016. Japan's tourism-led foreign direct investment inflows: An empirical study. Econ. Modell., 52: 435-441.

Tomohara, A., 2017. Relationships between international tourism and modes of foreign market access. Intl. Econ., 152: 21-25.

Usmita, F., 2012. [Disengagement: Counter-terrorism strategy in Indonesia]. Master Thesis, University of Indonesia, Depok, Indonesia. (In Indonesia)

Vanlauwe, B., A. Bationo, J. Chianu, K.E. Giller and R. Merckx et al., 2010. Integrated soil fertility management: Operational definition and consequences for implementation and dissemination. Outlook Agric., 39: 17-24.

Wadley, M.R., T.D. Jickells and K.J. Heywood, 2014. The role of iron sources and transport for Southern Ocean productivity. Deep Sea Res. Part I. Oceanogr. Res. Pap., 87: 82-94. 
Wasak, K. and M. Drewnik, 2015. Land use effects on soil organic carbon sequestration in calcareous Leptosols in former pastureland a case study from the Tatra Mountains (Poland). Solid Earth, 6: 1103-1115.

Waxman, D., 2011. Living with terror, not living in terror: The impact of chronic terrorism on Israeli society. Perspect. Terrorism, 5: 4-26.

Webber, D. and A.W. Kruglanski, 2018. The social psychological makings of a terrorist. Curr. Opin. Psychol., 19: 131-134.

Wiltgen, A., C. Arbona, L. Frankel and B.C. Frueh, 2015. Interpersonal trauma, attachment insecurity and anxiety in an inpatient psychiatric population. $\mathrm{J}$. Anxiety Disord., 35: 82-87.

Younas, J., 2015. Terrorism, openness and the Feldstein-horioka paradox. Eur. J. Political Econ., 38: $1-11$.

Young, A.M. and D.H. Gray, 2011. Insurgency, guerilla warfare and terrorism: Conflict and its application for the future. Global Secur. Stud., 2: 61-71.
Young-McCaughan, S., M.O. Bingham, C.A. Vriend, A.W. Inman and K.M. Gaylord et al., 2017. The impact of symptom burden on the health status of service members with extremity trauma. Nurs. Outlook, 65: S61-S70.

Yusuf, A.J., H.Y. Maitama, M.A. Amedu, M. Ahmed and H.N. Mbibu, 2012. Socio-demographic correlates of psychological distress among male patients with infertility in Zaria, Nigeria. Afr. J. Urology, 18: 170-174.

Zaiets, O. and R.M. Poch, 2016. Micromorphology of organic matter and humus in Mediterranean mountain soils. Geoderma, 272: 83-92.

Zhang, H., 2014. The poverty trap of education: Education-poverty connections in Western China. Intl. J. Educ. Dev., 38: 47-58.

Zulkarnain, M., B. Prasetya and S. Soemarno, 2013. [Effect of Compost, manure and custom-bio against soil characteristic, growth and result of sugar cane (Saccharum officinarum L.) at Entisol in NgrangkahPawon Garden, Kediri (In Indonesian)]. Indonesian Green Technol. J., 2: 45-52. 